\title{
ТОКСИНЫ МИКРОМИЦЕТОВ В ГЕНЕРАТИВНЫХ ОРГАНАХ РАСТЕНИЙ СЕМЕЙСТВА Fabaceae
}

\section{Г.П. КОНОНЕНКО $~$, А.А. БУРКИН}

При изучении роли ассоциированных микроскопических грибов в адаптации растений к внешним воздействиям внимание исследователей сосредоточено на таких ключевых аспектах, как смещение состава внутренней микобиоты в процессе роста, направленность колонизации грибами вегетативных и генеративных органов, а также сопутствующие изменения в метаболическом статусе организма (Ј.A. Wearn с соавт., 2012; V. Arbona с соавт., 2013; J. Hong с соавт., 2016). У луговых трав семейства Fabaceae изучена динамика накопления ДНК грибов Alternaria, Cladosporium и Fusarium в разные месяцы сбора растений (О.П. Гаврилова с соавт., 2017; А.С. Орина с соавт., 2018) и выявлены сезонные колебания в содержании токсичных метаболитов, свойственных этим группам микромицетов (А.А. Буркин, Г.П. Кононенко, 2018, 2019). У клевера лугового, клевера ползучего, козлятника восточного, люпина многолистного и донников установлена преимущественная локализация микотоксинов в листовых пластинках (Г.П. Кононенко с соавт., 2019). В настоящем исследовании нами впервые описаны комплексы токсичных метаболитов несовершенных грибов в генеративных органах бобовых растений. Целью работы стало изучение компонентного состава и содержания микотоксинов в цельных растениях, цветках и плодах многолетних бобовых трав из шести родов семейства Fabaceae. Луговые травы родов Trifolium L. - клевер луговой (T. pratense L.), клевер гибридный (T. hybridum L.), клевер средний (T. medium L.), клевер ползучий (T. repens L.), Lathyrus L. - чина луговая (L. pratensis L.), чина весенняя (L. vernus (L.) Bernh.), Vicia L. - горошек заборный (V. sepium L.), горошек мышиный (V. cracca L.), Lotus L. лядвенец рогатый (L. corniculatus L. S.I.), Lupinus L. - люпин многолистный (L. polyphyllus Lindl.) и Galega L. - козлятник восточный (G. orientalis Lam.) отбирали из естественных травостоев Московской области в мае-первой половине августа 2019 года, горошек лесной (V. sylvatica L.) и чину японскую (L. japonicus Willd. subsp. pubescens Korobkov) - во второй половине августа того же года на побережье Кандалакшского залива Белого моря (Республика Карелия). Надземные части растений, а также цветки и бобы выдерживали при комнатной температуре до воздушносухого состояния и измельчали в лабораторной мельнице. Для экстракции применяли смесь ацетонитрила и воды в объемном соотношении 84:16 при расходе 10 мл на 1 г навески. Экстракты после 10-кратного разбавления буферным раствором использовали для непрямого конкурентного иммуноферментного анализа. Содержание микотоксинов - T-2 токсина (T-2), дезоксиниваленола (ДОН), зеараленона (ЗЕН), фумонизинов (ФУМ), эргоалкалоидов (ЭА), альтернариола (АОЛ), роридина А (POA), афлатоксина В1 (AB1), стеригматоцистина (СТE), циклопиазоновой кислоты (ЦПК), эмодина (ЭМО), охратоксина А (ОА), цитринина (ЦИТ), микофеноловой кислоты (МФК), PR-токсина (PR) определяли с помощью коммерческих и исследовательских аттестованных иммуноферментных тест-систем (ГОСТ 31653-2012). Для генеративных органов большинства обследованных растений были выявлены как общие черты (сохранение профиля микотоксинов, типичного для целого растения, при отсутствии или снижении содержания ряда грибных метаболитов), так и особенности. В частности, в цветках трех видов рода Trifolium L. в целом сохранялся комплекс микотоксинов, свойственный вегетативной части, но при этом встречаемость и накопление фузариотоксинов были выше. Для цветков двух видов - клевера гибридного и клевера среднего была характерна сочетанная контаминация ОА и ЦИТ в сопоставимых количествах, редкая для растений. При общей низкой контаминации у лядвенца рогатого фузариотоксины Т-2, ДОН и ЗЕН присутствовали только в генеративных органах. У всех представителей родов Vicia, Lathyrus, Lupinus и Galega метаболический фон в цветках в целом был оценен как ослабленный, в бобах он оказался сходным с надземной частью без отчетливых признаков смены компонентного состава и резкого варьирования содержания микотоксинов.

Ключевые слова: бобовые травы, цветки, бобы, микотоксины, иммуноферментный анализ.

В последние годы при изучении механизмов адаптации к внешним воздействиям растения все чаще рассматривают как сложные системы, в состав которых входят микромицеты $(1,2)$. Между грибами и растением могут устанавливаться различные связи: от полной обособленности до совместного участия в биохимических процессах (3-5). К основным ответным реакциям растений на смену условий обитания относят смещение состава внутренней микобиоты и направленности колонизации грибами вегетативных 
и генеративных органов $(6,7)$, а также сопутствующие им изменения метаболического статуса организма (8-10).

У луговых трав семейства Fabaceae изучена динамика накопления ДНК грибов Alternaria, Cladosporium и Fusarium в разные месяцы сбора растений $(11,12)$ и выявлены сезонные колебания в содержании токсичных метаболитов, свойственных этим группам микромицетов (13-15). В отношении органотропности эндофитных грибов у этих растений получены предварительные данные (16), но для клевера лугового, клевера ползучего, козлятника восточного, люпина многолистного и донников установлена преимущественная локализация микотоксинов в листовых пластинках; тот же комплекс метаболитов с повышенным содержанием отдельных компонентов сохраняется в цветках у донников (Melilotus sp.) (17). Микотоксикологическое обследование генеративных органов у других представителей этого семейства не проводилось.

В настоящей работе нами впервые описаны комплексы токсичных метаболитов несовершенных грибов в генеративных органах бобовых растений.

Нашей целью стало изучение компонентного состава и содержания микотоксинов в цветках и бобах у многолетних бобовых растений родов Trifolium, Lathyrus, Vicia, Lotus, Lupinus и Galega.

Методика. Объектом исследования были луговые травы семейства Fabaceae с естественных травостоев Московской области, которые собирали регулярно, с недельными интервалами в мае-первой половине августа 2019 года. Согласно определителям $(18,19)$ травы были отнесены к шести родам: Trifolium L. - клевер луговой T. pratense L., клевер гибридный T. hybridum L., клевер средний T. medium L., клевер ползучий T. repens L.; Lathyrus L. - чина луговая L. pratensis L., чина весенняя L. vernus (L.) Bernh.; Vicia L. - горошек заборный V. sepium L., горошек мышиный V. cracca L.; Lotus L. - лядвенец рогатый L. corniculatus L. s.l., Lupinus L. - люпин многолистный (L. polyphyllus Lindl.); Galega L. - козлятник восточный G. orientalis Lam. Горошек лесной $V$. sylvatica L. и чина японская L. japonicus Willd. subsp. pubescens Korobkov были отобраны во второй половине августа того же года на побережье Кандалакшского залива Белого моря (Республика Карелия).

Надземные части растений, срезанные на высоте 3-5 см от поверхности почвы, а также отделенные от них цветки и бобы сразу после сбора помещали в проветриваемое помещение, выдерживали при комнатной температуре до воздушно-сухого состояния и измельчали в лабораторной мельнице. Для экстракции применяли смесь ацетонитрила и воды в объемном соотношении 84:16 при расходе 10 мл на 1 г навески. Экстракты после 10-кратного разбавления фосфатно-солевым буферным раствором $(\mathrm{pH} 7,4)$ c Tween 20 использовали для непрямого конкурентного иммуноферментного анализа.

Содержание микотоксинов - Т-2 токсина (Т-2), дезоксиниваленола (ДОН), зеараленона (ЗЕН), фумонизинов (ФУМ), эргоалкалоидов (ЭА), альтернариола (АОЛ), роридина А (РОА), афлатоксина В1 (АВ1), стеригматоцистина (СТЕ), циклопиазоновой кислоты (ЦПК), эмодина (ЭМО), охратоксина A (OA), цитринина (ЦИТ), микофеноловой кислоты (MФК), PRтоксина (PR) анализировали с помощью коммерческих и исследовательских аттестованных иммуноферментных тест-систем (ГОСТ 31653-2012. «Корма. Метод иммуноферментного определения микотоксинов». М., 2012). Нижние пределы количественных измерений составляли 1 (ЭА, АВ1), 2 (Т-2), 4 (ОА, СТЕ, РОА), 15 (АОЛ, ЗЕН, ЭМО), 20 (ЦИТ, МФК), 50 МКГ/КГ (ДОН, 
ФУМ, ЦПК, PR) и соответствовали 85 \% связывания антител.

Данные обрабатывали с помощью описательной статистики в программе Microsoft Excel 2013. Вычисляли долю положительных образцов $\left(n^{+}\right)$ от общего числа исследованных $(n)$, минимальное, максимальное содержание (мкг/кг) микотоксинов и среднее арифметическое значение показателя $(M)$ по положительным образцам.

Результаты. В вегетативной части клевера лугового, как и отмечалось ранее (9), наиболее распространенным фузариотоксином был Т-2, peгулярно обнаруживались ЭА, АОЛ, ЦПК, ЭМО, ОА, АВ1, МФК и PR, к редко выявляемым относились ЦИТ, СТЕ, отсутствовал РОА. В цветках компонентный состав в целом сохранялся, при этом показатели частоты встречаемости и содержания повышались для фузариотоксинов (Т-2, ДОН, ЗЕН, ФУМ), оставались неизменными для АОЛ, ОА и АВ1 и снижались по остальным компонентам (табл. 1).

1. Встречаемость и содержание микотоксинов в надземных частях (1) и цветках (2) растений рода Trifolium L. (Московская обл., 2019 год)

\begin{tabular}{|c|c|c|c|c|c|c|c|c|}
\hline \multirow{2}{*}{ Микотоксин } & \multicolumn{2}{|c|}{$\begin{array}{l}\text { Клевер луговой } \\
\text { T. pratense L. }\end{array}$} & \multicolumn{2}{|c|}{$\begin{array}{c}\text { Клевер гибридный } \\
T . \text { hybridum L. }\end{array}$} & \multicolumn{2}{|c|}{$\begin{array}{l}\text { Клевер средний } \\
\text { T. medium L. }\end{array}$} & \multicolumn{2}{|c|}{$\begin{array}{l}\text { Клевер ползучий } \\
\text { T. repens L. }\end{array}$} \\
\hline & $\begin{array}{c}1 \\
(n=13)\end{array}$ & $\begin{array}{c}2 \\
(n=13)\end{array}$ & $\begin{array}{c}1 \\
(n=8)\end{array}$ & $\begin{array}{c}2 \\
(n=8)\end{array}$ & $\begin{array}{c}1 \\
(n=4)\end{array}$ & $\begin{array}{c}2 \\
(n=3)\end{array}$ & $\begin{array}{c}1 \\
(n=9)\end{array}$ & $\begin{array}{c}2 \\
(n=9)\end{array}$ \\
\hline $\mathrm{T}-2$ & $\begin{array}{c}13 \\
2-8-55\end{array}$ & $\begin{array}{c}13 \\
2-69-795\end{array}$ & $\begin{array}{c}6 \\
3-4-7\end{array}$ & $\begin{array}{c}8 \\
2-10-16\end{array}$ & $\begin{array}{c}4 \\
2-6-9\end{array}$ & $\begin{array}{c}3 \\
8-65-180\end{array}$ & $\begin{array}{c}9 \\
2-5-15\end{array}$ & $\begin{array}{c}8 \\
2-83-470\end{array}$ \\
\hline дОН & $\begin{array}{c}3 \\
68-115-160\end{array}$ & $\begin{array}{c}8 \\
63-110-160\end{array}$ & $\begin{array}{c}2 \\
95,95\end{array}$ & $\begin{array}{c}7 \\
120-210-400\end{array}$ & - & ${ }^{2} 100,170$ & - & - \\
\hline $3 \mathrm{EH}$ & $\begin{array}{c}3 \\
19-22-25\end{array}$ & $\begin{array}{c}6 \\
16-21-32\end{array}$ & ${ }^{2} 17,17$ & $\begin{array}{c}7 \\
20-45-84\end{array}$ & $\begin{array}{c}4 \\
15-19-25\end{array}$ & $\begin{array}{c}3 \\
25-45-61\end{array}$ & $\begin{array}{c}3 \\
19-20-21\end{array}$ & $\begin{array}{c}3 \\
19-22-26\end{array}$ \\
\hline ФУМ & $\begin{array}{c}1 \\
90\end{array}$ & $\begin{array}{c}1 \\
250\end{array}$ & - & $\begin{array}{c}5 \\
85-195-300\end{array}$ & - & $\begin{array}{c}2 \\
200,355\end{array}$ & - & - \\
\hline АОЛ & $\begin{array}{c}13 \\
64-130-180\end{array}$ & $\begin{array}{c}13 \\
63-125-315\end{array}$ & $\begin{array}{c}8 \\
30-70-105\end{array}$ & $\begin{array}{c}8 \\
44-300-630\end{array}$ & $\begin{array}{c}4 \\
120-155-210\end{array}$ & $\begin{array}{c}3 \\
240-290-370\end{array}$ & $\begin{array}{c}9 \\
21-38-54\end{array}$ & $\begin{array}{c}9 \\
40-76-160\end{array}$ \\
\hline $\mathrm{OA}$ & $\begin{array}{c}13 \\
6-20-31\end{array}$ & $\begin{array}{c}13 \\
6-17-54\end{array}$ & $\begin{array}{c}5 \\
5-7-10\end{array}$ & $\begin{array}{c}8 \\
10-55-110\end{array}$ & $\begin{array}{c}4 \\
8-9-10\end{array}$ & $\begin{array}{c}3 \\
9-31-56\end{array}$ & - & $\begin{array}{c}4 \\
5-7-8\end{array}$ \\
\hline ЦИТ & $\begin{array}{c}3 \\
28-36-51\end{array}$ & $\stackrel{2}{38,40}$ & $\begin{array}{c}5 \\
21-39-59\end{array}$ & $\begin{array}{c}7 \\
30-79-180\end{array}$ & - & $\begin{array}{c}2 \\
32,49\end{array}$ & - & $\stackrel{2}{21,25}$ \\
\hline CTE & $\begin{array}{c}5 \\
12-17-21\end{array}$ & $\begin{array}{c}1 \\
30\end{array}$ & $\begin{array}{c}3 \\
12-17-22\end{array}$ & $\begin{array}{c}5 \\
12-41-75\end{array}$ & $\begin{array}{c}1 \\
16\end{array}$ & $\begin{array}{c}3 \\
24-29-37\end{array}$ & $\begin{array}{c}3 \\
12-13-13\end{array}$ & $\begin{array}{c}2 \\
21,38\end{array}$ \\
\hline $\mathrm{AB} 1$ & $\begin{array}{c}11 \\
1-2-4\end{array}$ & $\begin{array}{c}12 \\
1-3-8\end{array}$ & $\begin{array}{c}2 \\
1,2\end{array}$ & $\begin{array}{c}6 \\
2-5-9\end{array}$ & $\begin{array}{c}3 \\
1-1-1\end{array}$ & $\begin{array}{c}2 \\
4,8\end{array}$ & $\begin{array}{c}2 \\
2,2\end{array}$ & $\begin{array}{c}5 \\
1-2-2\end{array}$ \\
\hline ЦПК & $\begin{array}{c}13 \\
39-230-590\end{array}$ & $\begin{array}{c}13 \\
31-95-245\end{array}$ & $\begin{array}{c}8 \\
50-135-240\end{array}$ & $\begin{array}{c}8 \\
63-160-315\end{array}$ & $\begin{array}{c}4 \\
62-86-105\end{array}$ & $\begin{array}{c}3 \\
47-77-135\end{array}$ & $\begin{array}{c}9 \\
40-72-105\end{array}$ & $\begin{array}{c}9 \\
32-76-115\end{array}$ \\
\hline МФК & $\begin{array}{c}12 \\
26-44-100\end{array}$ & $\begin{array}{c}8 \\
22-40-94\end{array}$ & $\begin{array}{c}8 \\
25-36-52\end{array}$ & $\begin{array}{c}7 \\
45-90-125\end{array}$ & $\begin{array}{c}4 \\
26-39-60\end{array}$ & $\begin{array}{c}3 \\
58-61-64\end{array}$ & $\begin{array}{c}9 \\
16-28-40\end{array}$ & $\begin{array}{c}9 \\
24-33-50\end{array}$ \\
\hline ЭА & $\begin{array}{c}10 \\
1-10-47\end{array}$ & $\begin{array}{c}6 \\
1-6-27\end{array}$ & $\begin{array}{c}6 \\
1-7-15\end{array}$ & $\begin{array}{c}7 \\
3-18-50\end{array}$ & $\begin{array}{c}4 \\
1-5-10\end{array}$ & $\begin{array}{c}3 \\
3-4-4\end{array}$ & $\begin{array}{c}7 \\
2-3-12\end{array}$ & $\begin{array}{c}5 \\
1-2-4\end{array}$ \\
\hline ЭМО & $\begin{array}{c}13 \\
315-960-282\end{array}$ & $\begin{array}{c}13 \\
(115-300-850\end{array}$ & $\begin{array}{c}7 \\
10-355-2240\end{array}$ & $\begin{array}{c}8 \\
33-130-240\end{array}$ & $\begin{array}{c}4 \\
32-82-125\end{array}$ & $\begin{array}{c}3 \\
50-195-405\end{array}$ & $\begin{array}{c}9 \\
50-150-250\end{array}$ & $\begin{array}{c}9 \\
35-185-645\end{array}$ \\
\hline PR & $\begin{array}{c}12 \\
335-530-795\end{array}$ & $\begin{array}{c}7 \\
305-405-575\end{array}$ & - & $\begin{array}{c}7 \\
400-585-795\end{array}$ & $\begin{array}{c}3 \\
425-530-670\end{array}$ & $\begin{array}{c}3 \\
670-790-945\end{array}$ & - & - \\
\hline POA & - & - & - & $\begin{array}{c}1 \\
18\end{array}$ & - & $\begin{array}{c}2 \\
10,14\end{array}$ & - & - \\
\hline $\begin{array}{l}\text { П р и м е ч а н } \\
\text { АОЛ - альтерн } \\
\text { Кисин В1, ЦП } \\
\text { ЭМО - эмоди } \\
\text { в строках - чи } \\
\text { нижний предел } \\
\text { мальное-средне }\end{array}$ & $\begin{array}{l}\text { и е. T-2 - T } \\
\text { нариол, OA } \\
\text { K - циклоп } \\
\text { н, PR - PR- } \\
\text { сло положи }\end{array}$ & $\begin{array}{l}-2 \text { токсин, Д } \\
- \text { охратокси } \\
\text { тиазоновая к } \\
\text {-токсин, РО } \\
\text { тельных обр } \\
\text {; под ним у } \\
\text { ьное). Проче }\end{array}$ & $\begin{array}{l}\text { ОН - дезок } \\
\text { Ін А, ЦИТ } \\
\text { кислота, М } \\
\text { А- рориди } \\
\text { азцов }\left(n^{+}\right) \text {, } \\
\text { казано соде }\end{array}$ & $\begin{array}{l}\text { ксинивалено } \\
\text { - цитрини } \\
\text { ІФК - микс } \\
\text { Iн А; } n-\text { чи } \\
\text { содержащих }\end{array}$ & $\begin{array}{l}\text { л, ЗЕН - зе } \\
\text { І, СТЕ - с } \\
\text { офеноловая } \\
\text { сло исследо } \\
\text { х микотокси }\end{array}$ & $\begin{array}{l}\text { еараленон, } \\
\text { геригматоци } \\
\text { кислота, Э } \\
\text { ванных обр } \\
\text { ıны в колич }\end{array}$ & $\begin{array}{l}\text { ФУМ - фу } \\
\text { Істин, АВ } \\
\text { А - эргоа } \\
\text { азцов. Верх } \\
\text { гестве, прег }\end{array}$ & $\begin{array}{l}\text { монизины, } \\
\text { - афлато- } \\
\text { алкалоиды, } \\
\text { хняя цифра } \\
\text { вышающем } \\
\text { г/кг, мини- }\end{array}$ \\
\hline
\end{tabular}

Для растений клевера ползучего мы наблюдали повсеместную или близкую к ней встречаемость тех же микотоксинов, но в количествах, меньших, чем в клевере луговом (13). Цветки характеризовались повышенной концентрацией Т-2, тенденцией к увеличению содержания АОЛ, ОА, ЦИТ, ЭМО при сохранении тех же количеств ЦПК и МФК. У клевера гибридного 
и клевера среднего, занимающих промежуточное положение по содержанию микотоксинов (13), в цветках наблюдалась усиленная контаминация фузариотоксинами и АОЛ на фоне роста показателей по другим компонентам. Следовательно, у цветков и вегетативной части растений рода Trifolium наблюдались как общие черты, так и различия в составе и содержании микотоксинов (см. табл. 1).

У всех растений прослеживалась тенденция к большему накоплению фузариотоксинов в цветках. По-видимому, этот феномен связан со сходством их физиологических реакций, приводящих к общей направленности смещений в распределении микромицетов. Обнаружение всех анализируемых фузариотоксинов предполагает сочетанную контаминацию цветков клевера лугового, клевера гибридного и клевера среднего комплексом грибов Fusarium, идентификация которых пока не проводилась. Следует отметить, что за последние годы в составе эндофитов у филогенетически разнообразной группы дикорастуших злаковых трав показано присутствие токсигенных видов, в частности $F$. graminearum Schw., F. sporotrichioides Sherb., F. culmorum (W.G. Sm.) Sacc., и начато изучение их распределения в листьях, соцветиях и семенах (20-23).

К числу межвидовых особенностей относится и возрастание накопления АОЛ в цветках, особенно резко выраженное у клевера гибридного, менее отчетливо - у клевера среднего и клевера ползучего и не свойственное клеверу луговому. Важно отметить, что в злаковых травах активный продуцент этого токсина - мелкоспоровый вид Alternaria alternata - относят к типичным эндофитам (7).

Кроме того, в цветках клевера гибридного и клевера среднего выявляли ОА и ЦИТ в сопоставимых количествах, что было весьма необычно (см. табл. 1). Подобная ситуация встречается крайне редко. Ее наблюдали только у одного из 22 обследованных видов бобовых - солодки голой (Glycyrrhiza glabra L.) (15) и не отмечали у крестоцветных (17). Одновременная встречаемость этих токсинов описана как у высших растений, так и у лишайников (24), но, как правило, количества ЦИТ на порядок превышают установленные для ОА. Совместное присутствие этих микотоксинов с частотой 38 \% выявлено и в зерне, но не в равных количествах (25). Ясности в отношении источников ОА и ЦИТ в травах пока нет, однако известно, что условия обитания оказывают заметное влияние на биосинтетические процессы у микромицета Penicillium verrucosum (26-28), способного продуцировать оба метаболита (29). В цветках клевера лугового и клевера ползучего ЦИТ удалось обнаружить лишь в части образцов в количествах, близких к пределу его определения (см. табл. 1), а в семенах этих растений был детектирован только ОА и отсутствовал ЦИТ (неопубликованные данные авторов).

Микотоксикологическая оценка одного из представителей рода $\mathrm{Lo}$ tus - лядвенца рогатого, выполненная в настоящей работе впервые, показала, что в надземной части растения комплекс грибных метаболитов включал АОЛ, ЦПК и ЭМО, а также ОА и ЭА в меньших количествах (табл. 2). В цветках при сохранении трех основных контаминантов обнаружить ОА и ЭА в тех же количествах не удалось, но были детектированы MФК и PR. Бобы по составу оказались схожи с вегетативной массой и отличались лишь повышенным содержанием ЭМО. Фузариотоксины были обнаружены только в цветках и бобах: Т-2 во всех образцах, ЗЕН и ДОН в отдельных случаях. Эта особенность представляет несомненный научный интерес и указывает на необходимость более детального обследования L. corniculatus на расши- 
ренных выборках материала.

У двух видов Vicia (V. sepium и $V$. cracca), известных слабой контаминацией микотоксинами (15), прослеживалась тенденция к снижению их количества в цветках по сравнению с вегетативной частью, при этом встречаемость и концентрации АОЛ оставались прежними, а по ЭА оба показателя снижались (см. табл. 2). У горошка лесного (V. sylvatica), отобранного нами в Карелии, в наземной части и цветках содержание АОЛ также было сопоставимым (25 и 32 мкг/кг), а различия по ЭА (30 и 1 мкг/кг) оказались весьма значительными.

2. Встречаемость и содержание микотоксинов в надземных частях (1), цветках (2) и бобах (3) лядвенца рогатого и растений рода Vicia L. (Московская обл., 2019 год)

\begin{tabular}{|c|c|c|c|c|c|c|c|}
\hline \multirow{2}{*}{ Микотоксин } & \multicolumn{2}{|c|}{$\begin{array}{c}\text { Горошек заборный } \\
\text { V. sepium L. }\end{array}$} & \multicolumn{2}{|c|}{$\begin{array}{c}\text { Горошек мышиный } \\
\text { V. cracca L. }\end{array}$} & \multicolumn{3}{|c|}{$\begin{array}{l}\text { Лядвенец рогатый } \\
\text { L. corniculatus L. s.l. }\end{array}$} \\
\hline & $\begin{array}{c}1 \\
(n=4)\end{array}$ & $\begin{array}{c}2 \\
(n=4)\end{array}$ & $\begin{array}{c}1 \\
(n=5)\end{array}$ & $\begin{array}{c}2 \\
(n=5)\end{array}$ & $\begin{array}{c}1 \\
(n=4)\end{array}$ & $\begin{array}{c}2 \\
(n=3)\end{array}$ & $\begin{array}{c}3 \\
(n=3)\end{array}$ \\
\hline $\mathrm{T}-2$ & $\begin{array}{l}1 \\
3\end{array}$ & 2,3 & 2,3 & 2,2 & - & $\begin{array}{c}3 \\
2-3-3\end{array}$ & $\begin{array}{c}3 \\
3-6-10\end{array}$ \\
\hline ДОН & - & - & 10 & 1 & - & - & $\begin{array}{c}1 \\
71\end{array}$ \\
\hline 3EH & - & - & $\begin{array}{c}1 \\
16\end{array}$ & - & - & $\begin{array}{c}1 \\
16\end{array}$ & 16,18 \\
\hline ФУМ & - & - & 380,420 & - & - & - & - \\
\hline АОЛ & $\begin{array}{c}4 \\
20-26-34\end{array}$ & $\begin{array}{c}4 \\
20-29-35\end{array}$ & $\begin{array}{c}4 \\
14-29-38\end{array}$ & $\begin{array}{c}5 \\
23-33-47\end{array}$ & $\begin{array}{c}4 \\
22-36-50\end{array}$ & $\begin{array}{c}3 \\
31-42-48\end{array}$ & $\begin{array}{c}3 \\
40-41-44\end{array}$ \\
\hline OA & $\begin{array}{l}1 \\
5\end{array}$ & - & $\begin{array}{l}1 \\
8\end{array}$ & $\begin{array}{l}1 \\
9\end{array}$ & $\begin{array}{c}4 \\
5-7-8\end{array}$ & - & $\begin{array}{c}3 \\
5-10-18\end{array}$ \\
\hline ЦИТ & $\begin{array}{c}1 \\
47\end{array}$ & - & $\begin{array}{c}1 \\
30\end{array}$ & - & - & - & $\begin{array}{c}1 \\
23\end{array}$ \\
\hline CTE & $\begin{array}{c}1 \\
14\end{array}$ & - & 12,17 & - & - & - & - \\
\hline $\mathrm{AB} 1$ & - & - & - & - & - & - & - \\
\hline ЦПК & $\begin{array}{c}4 \\
160-200-275\end{array}$ & $\begin{array}{c}4 \\
79-140-195\end{array}$ & $\begin{array}{c}5 \\
50-130-200\end{array}$ & $\begin{array}{c}5 \\
48-100-160\end{array}$ & $\begin{array}{c}3 \\
39-65-97\end{array}$ & $\begin{array}{c}3 \\
52-70-105\end{array}$ & $\begin{array}{c}2 \\
61,105\end{array}$ \\
\hline МФК & $\begin{array}{c}4 \\
16-23-38\end{array}$ & $\begin{array}{c}4 \\
14-16-18\end{array}$ & - & - & - & $\begin{array}{c}2 \\
13,20\end{array}$ & $\begin{array}{c}2 \\
25,32\end{array}$ \\
\hline ЭА & $\begin{array}{c}4 \\
10-19-26\end{array}$ & $\begin{array}{c}3 \\
2-3-5\end{array}$ & $\begin{array}{c}5 \\
3-14-35\end{array}$ & $\begin{array}{c}3 \\
2-9-24\end{array}$ & $\begin{array}{c}3 \\
2-2-3\end{array}$ & - & $\begin{array}{c}2 \\
3,11\end{array}$ \\
\hline ЭМО & $\begin{array}{c}2 \\
13,25\end{array}$ & $\begin{array}{c}1 \\
16\end{array}$ & - & $\begin{array}{c}1 \\
25\end{array}$ & $\begin{array}{c}4 \\
40-75-140\end{array}$ & $\begin{array}{c}3 \\
49-75-120\end{array}$ & $\begin{array}{c}3 \\
165-205-250\end{array}$ \\
\hline PR & $10,2 \pi$ & - & - & - & - & $\begin{array}{c}1 \\
260\end{array}$ & - \\
\hline POA & - & - & - & - & - & - & - \\
\hline
\end{tabular}

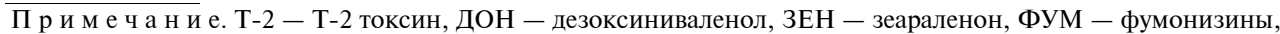
АОЛ - альтернариол, ОА - охратоксин А, ЦИТ - цитринин, СТЕ - стеригматоцистин, АВ1 - афлатокисин В1, ЦПК - циклопиазоновая кислота, МФК - микофеноловая кислота, ЭА - эргоалкалоиды, ЭМО - эмодин, PR - PR-токсин, POA - роридин А; $n$ - число исследованных образцов. Верхняя цифра в строках - число положительных образцов $\left(n^{+}\right)$, содержащих микотоксины в количестве, превышающем нижний предел измерений; под ним указано содержание соответствующего микотоксина (мкг/кг, минимальное-среднее-максимальное). Прочерк означает, что положительных образцов не обнаружили.

У двух видов рода Lathyrus, характеризующихся разной степенью контаминации (15), наблюдалось единообразное снижение содержания микотоксинов в цветках относительно вегетативной части, однако у чины весенней контаминация АОЛ и ЦПК сохранялась прежней (табл. 3), как и в образцах чины японской из географически удаленного ареала (Карелия) (содержание АОЛ в надземной части и цветках - соответственно 23 и 43 мкг/кг, ЦПК - 50 и 42 мКг/Кг).

Видовые особенности распространялись и на бобы. У чины весенней состав микотоксинов пополнялся T-2, ДОН и PR, была снижена частота выявления МФК при том же регулярном обнаружении и постоянстве концентраций АОЛ и ЦПК, что и в надземной части, а у чины луговой отчет- 
ливых различий в контаминации бобов и вегетирующего растения практически не наблюдалось (см. табл. 3).

3. Встречаемость и содержание микотоксинов в надземных частях (1), цветках (2) и бобах (3) растений рода Lathyrus L. (Московская обл., 2019 год)

\begin{tabular}{|c|c|c|c|c|c|c|}
\hline \multirow{2}{*}{ Микотоксин } & \multicolumn{3}{|c|}{$\begin{array}{c}\text { Чина весенняя } \\
\text { L. vernus (L.) Bernh. }\end{array}$} & \multicolumn{3}{|c|}{$\begin{array}{l}\text { Чина луговая } \\
\text { L. pratensis L. }\end{array}$} \\
\hline & $\begin{array}{c}1 \\
(n=20)\end{array}$ & $\begin{array}{c}2 \\
(n=4)\end{array}$ & $\begin{array}{c}3 \\
(n=8)\end{array}$ & $\left(\begin{array}{c}1 \\
(n=9)\end{array}\right.$ & $\begin{array}{c}2 \\
(n=4)\end{array}$ & $\begin{array}{c}3 \\
(n=6)\end{array}$ \\
\hline $\mathrm{T}-2$ & - & - & $\begin{array}{c}3 \\
2-2-3\end{array}$ & $\begin{array}{c}9 \\
2-6-10\end{array}$ & $\begin{array}{c}4 \\
2-3-6\end{array}$ & $\begin{array}{c}5 \\
3-4-5\end{array}$ \\
\hline ДОН & - & - & $\begin{array}{c}4 \\
64-74-83\end{array}$ & $\begin{array}{c}7 \\
105-220-455\end{array}$ & $\begin{array}{c}1 \\
97\end{array}$ & $\frac{5}{125-175-240}$ \\
\hline $3 \mathrm{EH}$ & - & - & - & $\begin{array}{c}9 \\
19-36-52\end{array}$ & $\begin{array}{c}4 \\
16-27-42\end{array}$ & $\begin{array}{c}6 \\
24-29-33\end{array}$ \\
\hline ФУМ & - & - & - & $\begin{array}{c}4 \\
95-450-1095\end{array}$ & - & $\begin{array}{c}4 \\
89-205-355\end{array}$ \\
\hline АОЛ & $\begin{array}{c}20 \\
21-59-100\end{array}$ & $\begin{array}{c}4 \\
39-54-63\end{array}$ & $\begin{array}{c}8 \\
33-54-86\end{array}$ & $\begin{array}{c}9 \\
60-350-960\end{array}$ & $\begin{array}{c}4 \\
10-160-580\end{array}$ & $\begin{array}{c}6 \\
98-150-190\end{array}$ \\
\hline $\mathrm{OA}$ & $\begin{array}{c}4 \\
4-5-6\end{array}$ & - & $\begin{array}{c}6 \\
5-12-23\end{array}$ & $\begin{array}{c}9 \\
16-36-59\end{array}$ & $\begin{array}{c}1 \\
32\end{array}$ & $\begin{array}{c}6 \\
43-66-105\end{array}$ \\
\hline ЦИТ & $\begin{array}{c}4 \\
23-30-40\end{array}$ & - & $\begin{array}{c}3 \\
24-27-33\end{array}$ & $\begin{array}{c}8 \\
40-65-125\end{array}$ & $\begin{array}{c}1 \\
32\end{array}$ & $\begin{array}{c}6 \\
32-42-56\end{array}$ \\
\hline CTE & $\begin{array}{c}6 \\
11-15-19\end{array}$ & - & 12,15 & $\begin{array}{c}9 \\
19-63-120\end{array}$ & $\begin{array}{c}1 \\
10\end{array}$ & $\begin{array}{c}6 \\
22-30-38\end{array}$ \\
\hline $\mathrm{AB} 1$ & $\begin{array}{c}2 \\
2,2\end{array}$ & - & $\begin{array}{c}3 \\
2-3-4\end{array}$ & $\begin{array}{c}9 \\
3-10-19\end{array}$ & $\begin{array}{l}1 \\
2\end{array}$ & $\begin{array}{c}6 \\
2-3-4\end{array}$ \\
\hline ЦПК & $\begin{array}{c}18 \\
72-160-255\end{array}$ & $\begin{array}{c}4 \\
79-130-180\end{array}$ & $\begin{array}{c}8 \\
74-115-225\end{array}$ & $\begin{array}{c}9 \\
63-145-315\end{array}$ & $\begin{array}{c}2 \\
66,79\end{array}$ & $\begin{array}{c}4 \\
53-65-78\end{array}$ \\
\hline МФК & $\begin{array}{c}10 \\
15-19-25\end{array}$ & - & $\begin{array}{c}1 \\
16\end{array}$ & $\begin{array}{c}9 \\
29-46-79\end{array}$ & $\begin{array}{c}2 \\
13,22\end{array}$ & $\begin{array}{c}5 \\
26-41-60\end{array}$ \\
\hline ЭА & $\begin{array}{c}20 \\
3-21-100\end{array}$ & $\begin{array}{c}4 \\
4-6-8\end{array}$ & $\begin{array}{c}5 \\
2-8-20\end{array}$ & $\begin{array}{c}9 \\
4-36-155\end{array}$ & $\begin{array}{l}1 \\
3\end{array}$ & $\begin{array}{c}6 \\
3-7-12\end{array}$ \\
\hline ЭМО & $\begin{array}{c}9 \\
12-21-38\end{array}$ & $\begin{array}{c}2 \\
19,19\end{array}$ & $\begin{array}{c}6 \\
12-24-60\end{array}$ & $\begin{array}{c}9 \\
17-71-130\end{array}$ & $\begin{array}{c}1 \\
18\end{array}$ & $\begin{array}{c}6 \\
17-25-37\end{array}$ \\
\hline PR & - & - & $\begin{array}{c}1 \\
232\end{array}$ & $\begin{array}{c}4 \\
400-720-1585\end{array}$ & - & $\begin{array}{c}4 \\
425-610-815\end{array}$ \\
\hline POA & - & - & - & $\begin{array}{c}4 \\
14-185-255\end{array}$ & - & $\begin{array}{c}6 \\
3-44-110\end{array}$ \\
\hline $\begin{array}{l}\text { П р и м е ч а н и } \\
\text { АОЛ - альтерн } \\
\text { кисин В1, ЦПК } \\
\text { ЭМО - эмодин } \\
\text { в строках - чис } \\
\text { нижний предел } \\
\text { мальное-средне }\end{array}$ & $\begin{array}{l}\text { е. T-2 - T-2 } \\
\text { риол, ОА - } \\
\text { - циклопи } \\
\text { PR - PR-Tс } \\
\text { Iо положите } \\
\text { измерений; } \\
\text {-максимальн }\end{array}$ & $\begin{array}{l}\text { осин, ДОН } \\
\text { хратоксин А } \\
\text { оновая кисл } \\
\text { син, РОА - } \\
\text { ных образцс } \\
\text { д ним указа } \\
\text { ). Прочерк }\end{array}$ & $\begin{array}{l}\text { дезоксинива } \\
\text { ЦИТ - цитр } \\
\text { са, МФК - } \\
\text { оридин А; } n- \\
\left(n^{+}\right), \text {содерж } \\
\text { содержание } \\
\text { начает, что п }\end{array}$ & $\begin{array}{l}\text { ол, ЗЕН - зеа } \\
\text { Н, СТЕ - сте } \\
\text { офеноловая к } \\
\text { ясло исследова } \\
\text { Х микотоксин } \\
\text { ответствующег }\end{array}$ & $\begin{array}{l}\text { генон, ФУМ } \\
\text { матоцистин, } \\
\text { лота, ЭА - } \\
\text { ых образцов } \\
\text { количестве } \\
\text { микотоксина }\end{array}$ & $\begin{array}{l}\text { фумонизины } \\
\text { АВ1 - афлато- } \\
\text { ргоалкалоиды } \\
\text { Верхняя цифра } \\
\text { превышающем } \\
\text { мкг/кг, мини- } \\
\text { жили. }\end{array}$ \\
\hline
\end{tabular}

Для растений родов Lupinus и Galega, несмотря на контрастную ситуацию по содержанию микотоксинов (14), отличия генеративных органов от вегетативных имели общие черты (табл. 4). У люпина многолистного из 14 компонентов, характерных для надземной части, в цветках были найдены все, кроме ФУМ, ЦИТ и PR, а в бобах - 8, исключая ДОН, СТЕ, АВ 1 . Встречаемость и содержание всех остальных микотоксинов, кроме АОЛ, в цветках и бобах снижались. Для козлятника восточного прослеживалась в целом аналогичная тенденция: в цветках из 12 микотоксинов были выявлены 8, кроме ФУМ, ОА, ЦИТ, СТЕ, в бобах - 7, кроме ЗЕН и АВ1, с одним случаем детектирования ОА. Частота выявления Т-2, ЦПК, МФК и ЭМО снижалась при их неизменном среднем содержании (см. табл. 4).

Таким образом, несмотря на межвидовые особенности, для многолетних бобовых растений в целом свойственно сохранение в цветках комплексов микотоксинов, типичных для вегетативной части, с тенденцией к снижению их содержания. Возможно, у растений с продолжительным прерываемым циклом роста лишь часть продуцентов вовлечена в специфические процессы, сопровождающие переход к генеративной фазе развития. Следует отметить, что у двух видов однолетних крестоцветных растений 
(горчицы белой и капусты полевой) набор микотоксинов в цветках оказался значительно шире за счет группы фузариотоксинов ДОН, ДАС, ЗЕН, ФУМ, а также MФК, ЭМО и PR $(17,30)$. В связи с этим в дальнейшем представляет интерес обследование однолетних бобовых трав, редко встречающихся в биоценозах Средней России, таких как горошек узколистный Vicia angustifolia Reichard, горошек волосистый V. hirsula (L.) S.F.Gray, горошек четырехсемянный $V$. tetraspermum (L.) Schreb. и горошек паннонский $V$. pannonica Crantz.

4. Встречаемость и содержание микотоксинов в надземных частях (1), цветках (2) и бобах (3) растений родов Lupinus L. и Galega L. (Московская обл., 2019 год)

\begin{tabular}{|c|c|c|c|c|c|c|}
\hline \multirow{2}{*}{ Микотоксин } & \multicolumn{3}{|c|}{$\begin{array}{l}\text { Люпин многолистный } \\
\text { L. polyphyllus Lindl. }\end{array}$} & \multicolumn{3}{|c|}{$\begin{array}{c}\text { Козлятник восточный } \\
\text { G. orientalis Lam. }\end{array}$} \\
\hline & $\begin{array}{c}1 \\
(n=17)\end{array}$ & $\begin{array}{c}2 \\
(n=7)\end{array}$ & $\begin{array}{c}3 \\
(n=7)\end{array}$ & $\begin{array}{c}1 \\
(n=15)\end{array}$ & $\begin{array}{c}2 \\
(n=5)\end{array}$ & $\begin{array}{c}3 \\
(n=8)\end{array}$ \\
\hline $\mathrm{T}-2$ & 17 & 7 & 6 & 9 & 5 & 3 \\
\hline & $3-5-11$ & $4-6-9$ & $2-3-4$ & $2-3-4$ & $3-3-4$ & $2-2-3$ \\
\hline ДОН & $\begin{array}{c}16 \\
63-89-125\end{array}$ & $\begin{array}{c}1 \\
63\end{array}$ & - & - & - & - \\
\hline ЗЕH & $\begin{array}{c}17 \\
16-29-47\end{array}$ & $\begin{array}{c}7 \\
16-34-50\end{array}$ & $\begin{array}{c}4 \\
12-17-21\end{array}$ & $\begin{array}{c}7 \\
16-25-33\end{array}$ & $\begin{array}{c}5 \\
19-27-34\end{array}$ & - \\
\hline ФУМ & $\begin{array}{c}1 \\
56\end{array}$ & - & - & $\begin{array}{c}1 \\
95\end{array}$ & - & - \\
\hline АОЛ & $\begin{array}{c}17 \\
65-155-295\end{array}$ & $\begin{array}{c}7 \\
63-105-130\end{array}$ & $\begin{array}{c}7 \\
19-145-785\end{array}$ & $\begin{array}{c}15 \\
11-31-66\end{array}$ & $\begin{array}{c}5 \\
25-47-81\end{array}$ & $\begin{array}{c}8 \\
14-27-63\end{array}$ \\
\hline $\mathrm{OA}$ & $\begin{array}{c}14 \\
5-8-12\end{array}$ & $\begin{array}{c}4 \\
5-6-6\end{array}$ & $\begin{array}{c}2 \\
5,6\end{array}$ & $\begin{array}{l}1 \\
5\end{array}$ & - & $\begin{array}{l}1 \\
5\end{array}$ \\
\hline ЦИТ & $\begin{array}{c}5 \\
20-36-74\end{array}$ & - & - & $\begin{array}{c}3 \\
23-24-25\end{array}$ & - & - \\
\hline CTE & $\begin{array}{c}15 \\
12-24-33\end{array}$ & $\begin{array}{c}1 \\
15\end{array}$ & - & $\begin{array}{c}5 \\
11-18-38\end{array}$ & - & - \\
\hline $\mathrm{AB} 1$ & $\begin{array}{l}17 \\
3-5-8\end{array}$ & $\begin{array}{c}7 \\
2-3-4\end{array}$ & - & $\begin{array}{c}3 \\
2-2-2\end{array}$ & $\begin{array}{c}4 \\
2-2-2\end{array}$ & - \\
\hline ЦПК & $\begin{array}{c}17 \\
130-475-870\end{array}$ & $\begin{array}{c}7 \\
150-260-355\end{array}$ & $\begin{array}{c}4 \\
68-73-79\end{array}$ & $\begin{array}{c}14 \\
41-115-255\end{array}$ & $\begin{array}{c}5 \\
82-110-140\end{array}$ & $\begin{array}{c}4 \\
74-105-125\end{array}$ \\
\hline МФК & $\begin{array}{c}16 \\
13-29-47\end{array}$ & $\begin{array}{c}7 \\
18-23-29\end{array}$ & $\begin{array}{c}2 \\
14,16\end{array}$ & $\begin{array}{c}8 \\
15-22-37\end{array}$ & $\begin{array}{c}5 \\
16-20-22\end{array}$ & $\begin{array}{c}1 \\
20\end{array}$ \\
\hline ЭА & $\begin{array}{c}16 \\
8-70-160\end{array}$ & $\begin{array}{c}7 \\
2-4-10\end{array}$ & $\begin{array}{c}4 \\
3-9-16\end{array}$ & $\begin{array}{c}12 \\
3-12-50\end{array}$ & $\begin{array}{c}4 \\
2-3-4\end{array}$ & $\begin{array}{c}4 \\
2-3-3\end{array}$ \\
\hline ЭМО & $\begin{array}{c}17 \\
31-155-355\end{array}$ & $\begin{array}{c}7 \\
25-49-85\end{array}$ & $\begin{array}{c}6 \\
26-84-130\end{array}$ & $\begin{array}{c}8 \\
12-14-15\end{array}$ & $\begin{array}{c}4 \\
13-17-25\end{array}$ & $\begin{array}{c}2 \\
11,26\end{array}$ \\
\hline PR & $\begin{array}{c}7 \\
205-290-400\end{array}$ & - & - & - & - & - \\
\hline POA & - & - & - & - & - & - \\
\hline $\begin{array}{l}\text { П р и м е ч а н и } \\
\text { АОЛ - альтерна } \\
\text { кисин В1, ЦПК } \\
\text { ЭМО - эмодин, } \\
\text { в строках - чис } \\
\text { нижний предел } \\
\text { мальное-среднее }\end{array}$ & $\begin{array}{l}\text { T-2 - T-2 то } \\
\text { иол, ОА - о } \\
\text { - циклопиаз } \\
\text { PR - PR-ток } \\
\text { о положитель } \\
\text { змерений; по } \\
\text { максимально }\end{array}$ & $\begin{array}{l}\text { ин, ДОН - д } \\
\text { токсин А, Ц } \\
\text { овая кислота } \\
\text {, РОА - рор } \\
\text { х образцов ( } \\
\text { ним указано } \\
\text { Прочерк озн }\end{array}$ & $\begin{array}{l}\text { оксинивален } \\
\text { Г - цитрини } \\
\text { МФК - миг } \\
\text { дин А; } n-\text { ч } \\
\text { ), содержащи } \\
\text { держание со } \\
\text { ает, что полс }\end{array}$ & $\begin{array}{l}\text { ЗЕН - зеа } \\
\text { СТЕ - сте } \\
\text { реноловая к } \\
\text { то исследова } \\
\text { микотоксин } \\
\text { ветствующег } \\
\text { ительных об }\end{array}$ & $\begin{array}{l}\text { енон, ФУМ } \\
\text { матоцистин, } \\
\text { ота, ЭА - } \\
\text { Iх образцов. } \\
\text { количестве, } \\
\text { икотоксина }\end{array}$ & $\begin{array}{l}\text { румонизины } \\
31 \text { - афлато } \\
\text { оалкалоиды } \\
\text { рхняя цифр } \\
\text { евышающем } \\
\text { кг/кг, мини }\end{array}$ \\
\hline
\end{tabular}

Таксономическая принадлежность микромицетов, ответственных за формирование комплекса микотоксинов в травах, до сих пор остаются неясной. Тем не менее в составе микобиоты высших растений 17 семейств, включая Fabaceae, уже показано доминирование представителей родов Curvularia, Acremonium, Alternaria, Penicillium, Fusarium, Stemphylium и Cladosporium (16), среди которых известны потенциально токсигенные виды (31). Кроме того, в нем могут присутствовать и ассоциированные грибы других систематических групп, поскольку современная наука получает все больше подтверждений переноса участков геномов в процессе эволюции от одного организма к другому $(32,33)$. Нельзя исключать и участие в токсиногенезе собственно эндофитных грибов, вовлеченных во взаимовыгодный симбиоз 
Роль эндофитных грибов в ответных реакциях растений на биотические и абиотические воздействия остается в центре внимания исследователей (34-38). Однако сведения о распределении эндофитов по органам организма-хозяина пока крайне ограничены и противоречивы. На растениях 17 семейств, включая Fabaceae, показано, что ассоциированные с ними грибы локализованы преимущественно в стеблях и листьях, в меньшей степени заселяют цветы, плоды, колосья и соцветия, а к наиболее благоприятным органам для их существования относится корневая система (16). У злаковых (ежи сборной, пырея и тимофеевки) методом количественной ПЦР установлена органотропная приуроченность грибов Fusarium, Alternaria и Cladosporium: в генеративных органах (колосьях/метелках) количество ДНК было достоверно выше, чем в стеблях и листьях (39).

Анализ результатов, полученных в настоящей работе, показывает, что токсинообразующие микромицеты могут быть вовлечены в процессы формирования генеративных органов у бобовых растений и в ответной реакции на изменения в окружающей среде. Можно предположить, что они причастны к метаболическим смещениям, которые служат для передачи трансформированных сигналов от рецепторов, воспринимающих изменения внешних факторов через «возмущение» гормонального статуса, систему вторичных мессенджеров, активность генома или поведение цитоскелета (40). Учитывая такой характер взаимодействия с растением, ассоциированные токсинообразующие микромицеты скорее следует относить к симбионтам, чем к эндокомменсалам, хотя данные, полученные в рамках настоящей работы, не дают каких-либо оснований судить о типизации микромицетов, обеспечивающих продуцирование микотоксинов.

Итак, в генеративных органах многолетних бобовых трав родов Trifolium, Lathyrus, Vicia, Lotus, Lupinus и Galega комплексы микотоксинов в целом схожи с найденными в вегетативных частях и у отдельных видов имеют различия по содержанию или соотношению отдельных компонентов. Установлен ряд особенностей в контаминации цветков растений рода Trifolium: сочетанная встречаемость охратоксина А и цитринина в сопоставимых количествах ( $T$. hybridum L., T. medium L.), резко увеличенное содержание альтернариола (T. hybridum), повышенное накопление Т-2 токсина, дезоксиниваленола, зеараленона и фумонизинов (T. pratense, T. hybridum, T. medium) и Т-2 токсина (у T. repens). У двух видов рода Lathyrus общим признаком была тенденция к снижению содержания микотоксинов в цветках, а для бобов наблюдалось сходство с цельным растением (L. pratensis) и пополнение состава T-2 токсином, дезоксиниваленолом, PR-токсином со снижением частоты выявления микофеноловой кислоты (L. vernus). У лядвенца рогатого (Lotus corniculatus) фузариотоксины были обнаружены только в генеративных органах. У обследованных представителей родов Vicia, Lupinus и Galega метаболический фон в цветках в целом был ослабленным, а в бобах не имел отчетливых признаков смены компонентного состава и резкого варьирования содержаний. Для успешного продолжения работы по оценке вклада токсигенных микромицетов во внутренние процессы и ответные реакции растений на внешние факторы в качестве объектов перспективны таксономически близкие виды и подвиды родов Lotus, Vicia, Lupinus и Galega. Сравнительный микотоксикологический анализ генеративных и вегетирующих органов, проведенный нами, в дальнейшем целесообразно распространить на растения и других систематических групп, что позволит составить более определенные представления о физиологической 


\section{Л ИТ Е РАТ У РА}

1. Saikkonen K., Faeth S.H., Helander M., Sullivan T.J. Fungal endophytes: a continuum of interactions with host plants. Annual Review of Ecology and Systematics, 2003, 29(1): 319-343 (doi: 10.1146/annurev.ecolsys.29.1.319).

2. Rodriguez R.J., White J.F.Jr., Arnold A.E., Redman R.S. Fungal endophytes: diversity and functional roles. New Phytologist, 2009, 182(2): 314-330 (doi: 10.1111/j.1469-8137.2009.02773.x).

3. Card S.D., Faville M.J., Simpson W.R., Johnson R.D., Voisey C.R., de Bonth A.C.M., Hume D.E. Mutualistic fungal endophytes in the Triticeae - survey and description. FEMS Microbiology Ecology, 2014, 88(1): 94-106 (doi: 10.1111/1574-6941.12273).

4. Potshangbam M., Devi S.I., Sahoo D., Strobel G.A. Functional characterization of endophytic fungal community associated with Oryza sativa L. and Zea mays L. Frontiers in Microbiology, 2017, 8: 325 (doi: 10.3389/fmicb.2017.00325).

5. Sánchez Márquez S., Bills G.F., Zabalgogeazcoa I. The endophytic mycobiota of the grass Dactylis glomerata. Fungal Diversity, 2007, 27: 171-195.

6. Wearn J.A., Sutton B.C., Morley N.J., Gange A.C. Species and organ specificity of fungal endophytes in herbaceous grassland plants. Journal of Ecology, 2012, 100(5): 1085-1092 (doi: 10.1111/j.1365-2745.2012.01997.x).

7. Hodgson S., Cates C., Hodgson J., Morley N.J., Sutton B.C., Gange A.C. Vertical transmission of fungal endophytes is widespread in forbs. Ecology and Evolution, 2014, 4(8): 1199-1208 (doi: 10.1002/ece3.953).

8. Kusari S., Spiteller M. Metabolomics of endophytic fungi producing associated plant secondary metabolites: progress, challenges and opportunities. In: Metabolomics /U. Roessner (ed.). In Tech, London, 2012 (doi: 10.5772/31596).

9. Arbona V., Manzi M., de Ollas C., Gómez-Cadenas A. Metabolomics as a tool to investigate abiotic stress tolerance in plants. International Journal of Molecular Sciences, 2013, 14(3): 48854911 (doi: 10.3390/ijms14034885).

10. Hong J., Yang L., Zhang D., Shi J. Plant metabolomics: an indispensable system biology tool for plant science. International Journal of Molecular Sciences, 2016, 17(6): 767 (doi: 10.3390/ijms17060767).

11. Гаврилова О.П., Орина А.С., Гагкаева Т.Ю. Количественная оценка зараженности видов рода Trifolium грибами и контаминации микотоксинами. Агрохимия, 2017, 11: 58-66 (doi: 10.7868/S0002188117110072).

12. Орина А.С., Гаврилова О.П., Гагкаева Т.Ю. Выявление зараженности грибами однолетних и многолетних трав семейства Leguminosae методом количественной ПЦР. Becтник защиты растений, 2018, 2(96): 35-41.

13. Кононенко Г.П., Буркин А.А. Вторичные метаболиты микромицетов в растениях семейства Fabaceae рода Trifolium. Известия Российской академии наук. Серия биологическая, 2018, 2: 150-157 (doi: 10.7868/S0002332918020030).

14. Буркин А.А., Кононенко Г.П. Вторичные метаболиты микромицетов в растениях семейства Fabaceae родов Galega, Glycyrrhiza, Lupinus, Medicago, Melilotus. Известия Российской академии наук. Серия биологическая, 2018, 3: 267-274 (doi: 10.7868/S0002332918030037).

15. Кононенко Г.П., Буркин А.А. Вторичные метаболиты микромицетов в растениях семейства Fabaceae родов Lathyrus, Vicia. Известия Российской академии наук. Серия биологическая, 2019, 3: 229-235 (doi: 10.1134/S0002332919030044).

16. Бобушева С.Т., Доолоткельдиева Т.Д. Эндофитные грибы-симбионты высших растений различных экосистем Кыргызстана. Fen Bilimleri Dergisi (Journal of Natural Science), 2008, 9: $1-8$.

17. Кононенко Г.П., Зотова Е.В., Устюжанина М.И. Распределение микотоксинов по органам у бобовых и крестоцветных растений. В сб.: Успехи медицинской микологии. М., 2019, 20 : 649-653.

18. Губанов И.А., Киселева К.В., Новиков В.С., Тихомиров В.Н. Иллюстрированный определитель растений Средней России. Том 2. М., 2003.

19. Скворцов В.Э. Иллюстрированное руководство для ботанических практик и экскурсий в Средней России. М., 2004.

20. Inch S., Gilbert J. The incidence of Fusarium species recovered from inflorescences of wild grasses in southern Mannitoba. Canadian Journal of Plant Pathology, 2003, 25(4): 379-383 doi: 10.1080/07060660309507093).

21. Harrow S.A., Farrokhi-Nejad R., Pitman A.R., Scott I.A.W., Bentley A., Hide C., Cromey M.G. Characterization of New Zealand Fusarium populations using a polyphasic approach differentiates the $F$. avenaceum $/ F$. acuminatum $/ F$. tricinctum species complex in cereal and grassland systems. Fungal Biology, 2010, 114(4): 293-311 (doi: 10.1016/j.funbio.2010.01.005). 
22. Postic J., Cosic J., Vrandecic K., Jurkovic D., Salch A.A., Leslie J.F. Diversity of Fusarium species isolated from weeds and plant debris in Croatia. Journal of Phytopathology, 2012, 160(2): 76-81 (doi: 10.1111/j.1439-0434.2011.01863.x).

23. Lofgren L.A., LeBlanc N.R., Certano A.K., Nachtigall J., LaBine K.M., Riddle J., Broz K., Dong Y., Bethan B., Kafer C.W., Kistler H.C. Fusarium graminearum: pathogen or endophyte of North American grasses? New Phytologist, 2017, 217(3): 1203-1212 (doi: 10.1111/nph.14894).

24. Буркин А.А., Кононенко Г.П. Вторичные метаболиты грибов (микотоксины) в лишайниках разной таксономической принадлежности. Известия Российской академии наук. Серия биологическая, 2014, 3: 228-235.

25. Kononenko G.P., Burkin A.A. Peculiarities of feed contamination with citrinin and ochratoxin A. Agricultural Sciences, 2013, 4(1): 34-38 (doi: 10.4236/as.2013.41006).

26. Wawrzyniak J., Waskiewicz A. Ochratoxin A and citrinin production by Penicillium verrucosum on cereal solid substrates. Food Additives and Contaminants, Part A, 2014, 31(1): 139-148 (doi: 10.1080/19440049.2013.861933).

27. Schmidt-Heydt M., Stoll D., Schütz P., Geisen R. Oxidative stress induces the biosynthesis of citrinin by Penicillium verrucosum at the expanse of ochratoxin. International Journal of Food Microbiology, 2015, 192: 1-6 (doi: 10.1016/j.ijfoodmicro.2014.09.008).

28. Geisen R., Schmidt-Heydt M., Touhami N., Himmelsbach A. New aspects of ochratoxin A and citrinin biosynthesis in Penicillium. Current Opinion in Food Science, 2018, 23: 23-31 (doi: 10.1016/j.cofs.2018.04.001).

29. Larsen T.O., Svendsen A., Smedsgaard J. Biochemical characterization of ochratoxin A-producing strains of the genus Penicillium. Applied and Environmental Microbiology, 2001, 67(8): 36303635 (doi: 10.1128/AEM.67.8.3630-3635.2001).

30. Буркин А.А., Кононенко Г.П., Мосина Л.В. Первое микотоксикологическое исследование горчицы белой (Sinapis alba L.). Сельскохозяйственная биология, 2019, 54(1): 186-194 (doi: 10.15389/agrobiology.2019.1.186rus).

31. Moretti A., Logrieco A.F., Susca A. Mycotoxins: an underhand food problem. In: Mycotoxigenic Fungi. Methods and Protocols /A. Moretti, A. Susca (eds.). Humana Press, New York, NY, 2017: 3-12 (doi: 10.1007/978-1-4939-6707-0).

32. Ali H., Ries M.I., Nijland J.G., Lankhorst P.P., Hankemeier T., Bovenberg R.A.L., Vreeken R.J., Driessen A.J.M. A branched biosynthetic pathway is involved in production of roquefortine and related compounds in Penicillium chrysogenum. PLoS One, 2013, 8(6): e65328 (doi: 10.1371/journal.pone.0065328).

33. Santana M.F., Queiroz M.V. Transposable elements in fingi: A genomic approach. Scientific Journal of Genetics and Gene Therapy, 2015, 1(1): 012-016.

34. Благовещенская Е.Ю. Эндофит-растение как сложная динамическая система. В сб.: Микология сегодня /Под ред. Ю.Т. Дьякова, А.Ю. Сергеева. М., 2011, 2: 126-134.

35. van Kan J.A.L., Shaw M.W., Grant-Downton R.T. Botrytis species: relentless necrotropic thugs or endophytes gone roque? Molecular Plant Pathology, 2014, 15(9): 957-961 (doi: 10.1111/mpp.12148).

36. Busby P.E., Ridout M., Newcombe G. Fungal endophytes: modifiers of plant disease. Plant Molecular Biology, 2016, 90(6): 645-655 (doi: 10.1007/s11103-015-0412-0).

37. Harrison J.G., Griffin E.A. The diversity and distribution of endophytes across biomes, plant phylogeny and host tissues: how far have we come and where do we go from here? Environmental Microbiology, 2020, 22(6): 2107-2123 (doi: 10.1111/1462-2920.14968).

38. Vorob'eva I., Toropova E. Fungi ecological niches of the genus Fusarium Link. Bio Web of Conferences, 2020, 24: 00095 (doi: 10.1051/bioconf/20202400095).

39. Орина А.С., Гаврилова О.П., Гагкаева Т.Ю. Колонизация культурных и дикорастущих злаковых растений грибами родов Alternaria, Cladosporium и Fusarium. Защита и карантин растений, 2017, 3: 25-27.

40. Чуб В.В. Физиология растений. Глава 7. Рост и развитие растений. 2003. Режим доступа: https://web.archive.org/web/20070120092003/http://herba.msu.ru/russian/departments/physiology /spezkursi/chub/index_7.html. Без даты.

Всероссийский НИИ ветеринарной санитарии, гигиены и экологии - филиал ФГБНУ ФНЦ ВИЭВ РАН, 123022 Россия, г. Москва, Звенигородское ш., 5, e-mail: kononenkogp@mail.ru $\bowtie$, aaburkin@mail.ru

Поступила в редакцию 18 июля 2021 года

\title{
TOXINS OF MICROMYCETES IN GENERATIVE ORGANS OF PLANTS OF THE FAMILY Fabaceae
}

\author{
G.P. Kononenko $\bowtie$, A.A. Burkin
}


All-Russian Research Institute for Veterinary Sanitation, Hygiene and Ecology - Branch of FSC ARRIEV RAS, 5, Zvenigorodskoe sh., Moscow, 123022 Russia, e-mail kononenkogp@mail.ru ( $₫$ corresponding author), aaburkin@mail.ru

ORCID:

Kononenko G.P. orcid.org/0000-0002-9144-615X

The authors declare no conflict of interests

Received July 18, 2021

Burkin A.A. orcid.org/0000-0002-5674-2818

doi: 10.15389 /agrobiology.2021.5.968eng

\section{Abstract}

During the study of the role of associated microscopic fungi in the adaptation of plants to external influences, researchers focus mainly on such key aspects as i) the shift in the composition of the internal mycobiota during growth, ii) the direction of fungal colonization of vegetative and generative organs, and iii) concomitant changes in the metabolic status of the plant organism (J.A., Wearn et al., 2012; V. Arbona et al., 2013; J. Hong et al., 2016). The dynamics of DNA accumulation of Alternaria, Cladosporium and Fusarium fungi in different months of plant growth was revealed in meadow grasses of the Fabaceae family (O.P. Gavrilova et al., 2017; A.S. Orina et al., 2018) and seasonal fluctuations in the content of toxic metabolites characteristic of these groups of micromycetes were found (A.A. Burkin, G.P. Kononenko, 2018, 2019). The predominant localization of mycotoxins in leaves was established for meadow clover, white clover, Caucasian goat's rue, Washington lupine and melilot (G.P. Kononenko et al., 2019). In this study, we describe for the first time the complexes of toxic fungi metabolites in the generative organs of legumes. The aim of the work was to study the component composition and content of mycotoxins in the whole plants, flowers and beans of perennial legumes of 6 genera of the Fabaceae family. Meadow grasses of the genera Trifolium L. - meadow clover ( $T$. pratense L.), alsike clover ( $T$. hybridum L.), zigzag clover ( $T$. medium L.), white clover (T. repens L.); of Lathyrus L. - meadow peavine (L. pratensis L.), spring peavine (L. vernus (L.) Bernh.); of Vicia L. - bush vetch (V. sepium L.), cow vetch (V. cracca L.); of Lotus L. - deer vetch (L. corniculatus L. s.1.); of Lupinus L. -Washington lupine (L. polyphyllus Lindl.), and of Galega L. Caucasian goat's rue ( $G$. orientalis Lam.) were collected from natural grass stands of the Moscow region in May-the first half of August 2019, wood vetch ( . sylvatica L.) and Japanese peavine (L. japonicus Willd. subsp. pubescens Korobkov) - in the second half of August of the same year on of the Kandalaksha Gulf of the White Sea (Republic of Karelia). The aboveground parts of plants, as well as flowers and beans, were kept at room temperature to an air-dry state and crushed in a laboratory mill. For extraction, a mixture of acetonitrile and water was used $(84: 16 \mathrm{v} / \mathrm{v})$ at the ratio of $10 \mathrm{ml}$ per $1 \mathrm{~g}$ of the sample. Extracts after 10-fold dilution with a buffer solution were assessed using indirect competitive enzyme immunoassay. The content of the mycotoxins $-\mathrm{T}-2$ toxin (T-2), deoxynivalenol $(\mathrm{DON})$, zearalenone $(\mathrm{ZEN})$, fumonisins (FUM), ergot alkaloids (EA), alternariol (AOL), roridin $\mathrm{A}(\mathrm{ROA})$, aflatoxin $\mathrm{B}_{1}\left(\mathrm{AB}_{1}\right)$, sterigmatocystin (STE), cyclopiazonic acid $(\mathrm{CPC})$, emodin (EMO), ochratoxin A (OA), citrinin (CIT), mycophenolic acid (IFC), PR-toxin (PR) was determined using commercial and research certified enzyme immunoassay systems (GOST 316532012). For the generative organs of most of the examined plants, both common features (preservation of the mycotoxin profile typical of the whole plant, with the absence or decrease in the content of a number of fungal metabolites) and peculiarities were revealed. In particular, in the flowers of three species of the genus Trifolium L., in general, the mycotoxin complex characteristic of the vegetative part was preserved, but the occurrence and accumulation of fusariotoxins were higher. The flowers of two species - alsike clover and zigzag clover were characterized by combined contamination of OA and CIT in comparable quantities, rare for plants. With a general low contamination, fusariotoxins T-2, DON and ZEN were present only in generative organs in the deer vetch. In all representatives of the genera Vicia, Lathyrus, Lupinus, and Galega the metabolic background in flowers as a whole was found weakened, in beans it turned out to be similar to the aboveground part without a sharp variation in the content of mycotoxins.

Keywords: legumes, flowers, beans, mycotoxins, ELISA. 